\title{
COMPARISON OF MICROSTRUCTURE AND EROSION WEAR RESISTANCE OF HVOF AND COLD SPRAYED COATINGS
}

\author{
${ }^{1}$ Anna KESLOVÁ, 'Šárka HOUDKOVÁ, 'Marek VOSTŘÁK, ' Jakub ANTOŠ \\ ${ }^{1}$ Research and Testing Institute, Tylova 46, Pilsen, 301 00, Czech Republic, EU
}

https://doi.org/10.37904/metal.2020.3551

\begin{abstract}
Thermally sprayed coatings are now used in many sectors of industry. In order to select the right material for a given application, it is necessary to know in detail the key properties of the coatings under consideration. Mechanical wear resistance is one of the most important and frequently sought properties. The aim of this work is to compare the properties of HVOF and Cold Sprayed coatings based on iron alloy (FeCrAlY), on tungsten carbide (WC-CoCr), on chromium carbide $\left(\mathrm{Cr}_{3} \mathrm{C}_{2}-\mathrm{NiCr}\right)$ and on $\mathrm{Ni}$ alloy $(\mathrm{NiCr})$. The structure of coatings and their resistance to erosive wear by solid particles are analyzed and discussed. The microstructures of Cold sprayed coatings show better properties than HVOF sprayed coatings, especially in terms of porosity, oxides content and coatings homogeneity.
\end{abstract}

Keywords: HVOF, Cold Spray, microstructure, erosion wear

\section{INTRODUCTION}

The aim of this study is to compare microstructure and solid particle erosion behavior of HVOF and Cold Sprayed coatings with different powder compositions. FeCrAlY coating is used as surface protection against corrosion at high temperatures (around $800-1000^{\circ} \mathrm{C}$ ). The high-temperature characteristics of this coating promote the formation of corrosion-resistant intermetallic phases, improving its properties and making the coating more resistant to an aggressive chemical environment [1]. Because of these properties, Fe24Cr8Al0.5Y coating is used in the engineering industry (protective coatings and coatings for heavy machinery), the most widespread application is a protective coating on ferritic/martensitic steels [2]. The coating based on tungsten carbide $\mathrm{WC}-10 \mathrm{Co} 4 \mathrm{Cr}$ is, due to its strength and outstanding wear resistance, suitable for application in many industries where machine parts are subjected to intensive abrasive wear. However, its resistance only applies to temperatures to $450-550^{\circ} \mathrm{C}[3,4]$. The $\mathrm{Cr}_{3} \mathrm{C}_{2}-25 \mathrm{NiCr}$ coating is used in high temperature applications up to $900^{\circ} \mathrm{C}$, due to the nickel-chromium alloy the coating is very resistant to corrosion and oxidation at higher temperatures till $900^{\circ} \mathrm{C}$ [5]. In contrast, in most cases at room temperature, the HVOF sprayed $\mathrm{C}_{3} \mathrm{C}_{2}-\mathrm{NiCr}$ coating exhibits the lowest wear resistance for dry and wet abrasive and erosive wear [6]. In this work, Ni-based coatings are concretely Ni-20Cr coatings sprayed by HVOF and Cold Spray technology. This type of coating has high-temperature characteristics such as resistance to oxidation and corrosion at temperatures up to $900^{\circ} \mathrm{C}$ [7]. According to Sidhu, the HVOF technology deposited $\mathrm{NiCr}$ coating is excellent in protecting against erosive wear [8]. The resulting properties of $\mathrm{NiCr}$ coatings, however, depend on the deposition technology used, in this work we will focus only on HVOF technology $[7,8]$ and Cold Spray technology [9]. 


\section{EXPERIMENTAL PROCEDURE}

\subsection{Materials and coatings deposition}

The HVOF sprayed coatings were all deposited onto carbon steel substrates and they were prepared from Amdry 9700 powder (FeCrAlY coating), WOKA 3652 powder (WC-CoCr coating), Amperit 588.074 powder ( $\mathrm{Cr}_{3} \mathrm{C}_{2}$-NiCr coating) and Amdry 4535 powder (NiCr coating) by using HP/HVOF TAFA JP5000 spraying gun. The cold sprayed coatings were prepared in Impact Innovations company in Germany using Sandwik Ospray $\mathrm{NiCr}$ powder (10-32 $\mu \mathrm{m}$ mesh). The surface of carbon steel substrates $(200 \times 100 \times 5)$ was grit blasted by $\mathrm{Al}_{2} \mathrm{O}_{3}$ using Impact Innovation Cold Spray system. The coating thickness was about $1 \mathrm{~mm}$ based on data from prior optimization of spraying parameters. The Sandwik Ospray NiCr powder (5-25 $\mu \mathrm{m}$ mesh) had the same spraying parameters as powder with 10-32 $\mu \mathrm{m}$ mesh.

\subsection{Characterization}

\subsubsection{Microstructure}

The microstructure of the coatings was evaluated on the coating cross-section prepared according to the standard method for metallographic sample preparation. The coatings were evaluated on a Nikon Epiphot 200 optical microscope and a JEOL JSM 6490 LV scanning electron microscope.

\subsubsection{Solid particle erosion wear}

The device for erosion wear by solid particles was designed and constructed at the Research and Testing Institute in Pilsen. The device utilizes the kinetic energy of solid particles $\left(\mathrm{Al}_{2} \mathrm{O}_{3}\right)$ that hit the surface of the coated samples due to the centrifugal force of the rotating disk. The angle of incidence of the particles on the sample is adjusted using the holders. The set angles of incidence of the solid particles were $15^{\circ}, 30^{\circ}, 45^{\circ}, 60^{\circ}$ and $90^{\circ}$, and two samples were tested at each angle, altogether ten samples. Selected parameters were used, such as a rotating disc speed of $47 \mathrm{~m} \cdot \mathrm{s}^{-1}$, an exposure time of 2 minutes and the $\mathrm{Al}_{2} \mathrm{O}_{3}$ as solid particles with a particle size of 212 to $250 \mu \mathrm{m}[10,11]$. After each wear cycle the samples were weighed and the values averaged. Three cycles were performed for each set of samples.

\section{RESULTS AND DISCUSSION}

The microstructure of the coatings is shown in Figure $\mathbf{1}$ and Figure 2. In Figure $\mathbf{1}$ are, FeCrAlY, WC-CoCr and $\mathrm{Cr}_{3} \mathrm{C}_{2}-\mathrm{NiCr}$ coatings sprayed with HVOF technology. The FeCrAlY coating has visible boundaries between individual splats, the porosity of the coating is minimal. On the other hand, the porosity of WC-CoCr coating is higher than FeCrAlY and the boundaries between splats are almost indistinguishable. $\mathrm{Cr}_{3} \mathrm{C}_{2}-\mathrm{NiCr}$ coating has indistinguishable boundaries between splats, the porosity is similar to that of WC-CoCr, this is expected because they are carbide-based coatings. At the same time, however, $\mathrm{Cr}_{3} \mathrm{C}_{2}-\mathrm{NiCr}$ coatings show darker and lighter spots in the coating, dark gray spots are $\mathrm{Cr}_{3} \mathrm{C}_{2}$ carbide and light $\mathrm{NiCr}$ matrix. Individual places change from place to place, the contrast of each area changes. Different shades of gray correspond to the different dissolution of carbide in the matrix, with the $\mathrm{NiCr}$ matrix always being the brightest point in the coating.

In Figure 2, NiCr coatings are sprayed with HVOF and Cold Spray technology. As mentioned in the previous paragraph, HVOF-sprayed coatings have visible individual boundaries between splats. This can be seen in the coating a), which is sprayed with HVOF technology. This coating also has a higher porosity. Two other $\mathrm{NiCr}$ coatings are sprayed with Cold Spray technology. Both cold-sprayed coatings have only a slight pore appearance, and due to the homogeneity of the coatings, the boundaries of splats are indistinguishable. The only difference between the two cold sprayed $\mathrm{NiCr}$ coatings is the powder distribution, 10-32 $\mu \mathrm{m}$ for b) and 5$25 \mu \mathrm{m}$ for $\mathrm{c}$ ). 

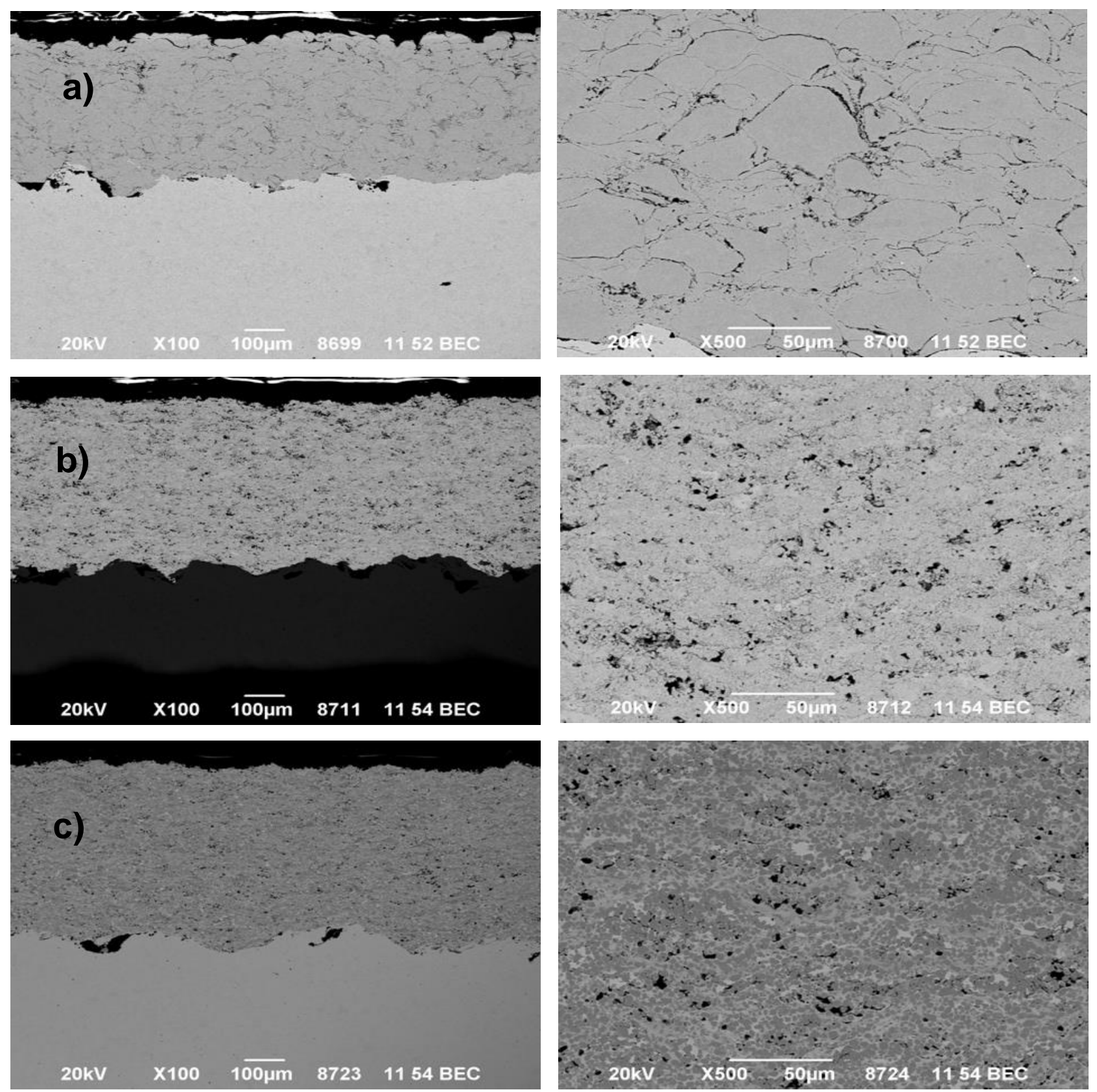

Figure 1 Microstructure of coatings on scanning electron microscope: a) FeCrAlY coating, b) WC-CoCr coating, c) $\mathrm{Cr}_{3} \mathrm{C}_{2}-\mathrm{NiCr}$ coating

The results of the solid particle erosion test are shown in Figure 3. It can be seen that all of these coatings are affected by the angles of incidence of the erodent. At the $90^{\circ}$ angle, the highest volume loss was for the $\mathrm{Cr}_{3} \mathrm{C}_{2}-$ $\mathrm{NiCr}$ coating. This result is expected for this coating, due to the fact that with the perpendicular impact of the erodent, this coating undergoes brittle breach and release of carbide particles, which results in higher losses. Hard but brittle coatings show higher erosive wear with the perpendicular impact of erodent particles [12]. At all other angles of $60^{\circ}, 45^{\circ}, 30^{\circ}$ and $15^{\circ}$, the HVOF deposited $\mathrm{NiCr}$ coating shows the highest volume losses, due to the weak boundaries between the individual splats (Figure 2a). The FeCrAlY coating has a similar course, whose smaller volume decreases increase with a lower value of the angle. The values of volume losses are lower than with the NiCr coating. The WC-CoCr coating does not have many differences between the angles as other coatings, due to its carbide structure, high hardness and toughness. Due to it is not as 
dependent on the angle of incidence of the erodent as other coatings. For WC- $\mathrm{CoCr}$ and $\mathrm{Cr}_{3} \mathrm{C}_{2}-\mathrm{NiCr}$ coatings, a similar course of erosive wear can be expected, because they are both carbide coatings. This statement is to some extent fulfilled, especially at angles of $30^{\circ}$ and $15^{\circ}$. The higher erosive wear of the $\mathrm{Cr}_{3} \mathrm{C}_{2}-\mathrm{NiCr}$ coating, especially at an angle of $90^{\circ}$, is due to its structure (Figure 1c) and its higher brittleness. NiCr coatings deposited with Cold Spray technology show the lowest erosive wear by solid particles of all the mentioned coatings, due to their high wear resistance and homogeneous structure. Of the two selected $\mathrm{NiCr}$ coatings, the coating with a particle size of 5-25 $\mu \mathrm{m}$ had the best results, which, thanks to the fineness of its particles, achieved the lowest overall erosive wear by solid particles.
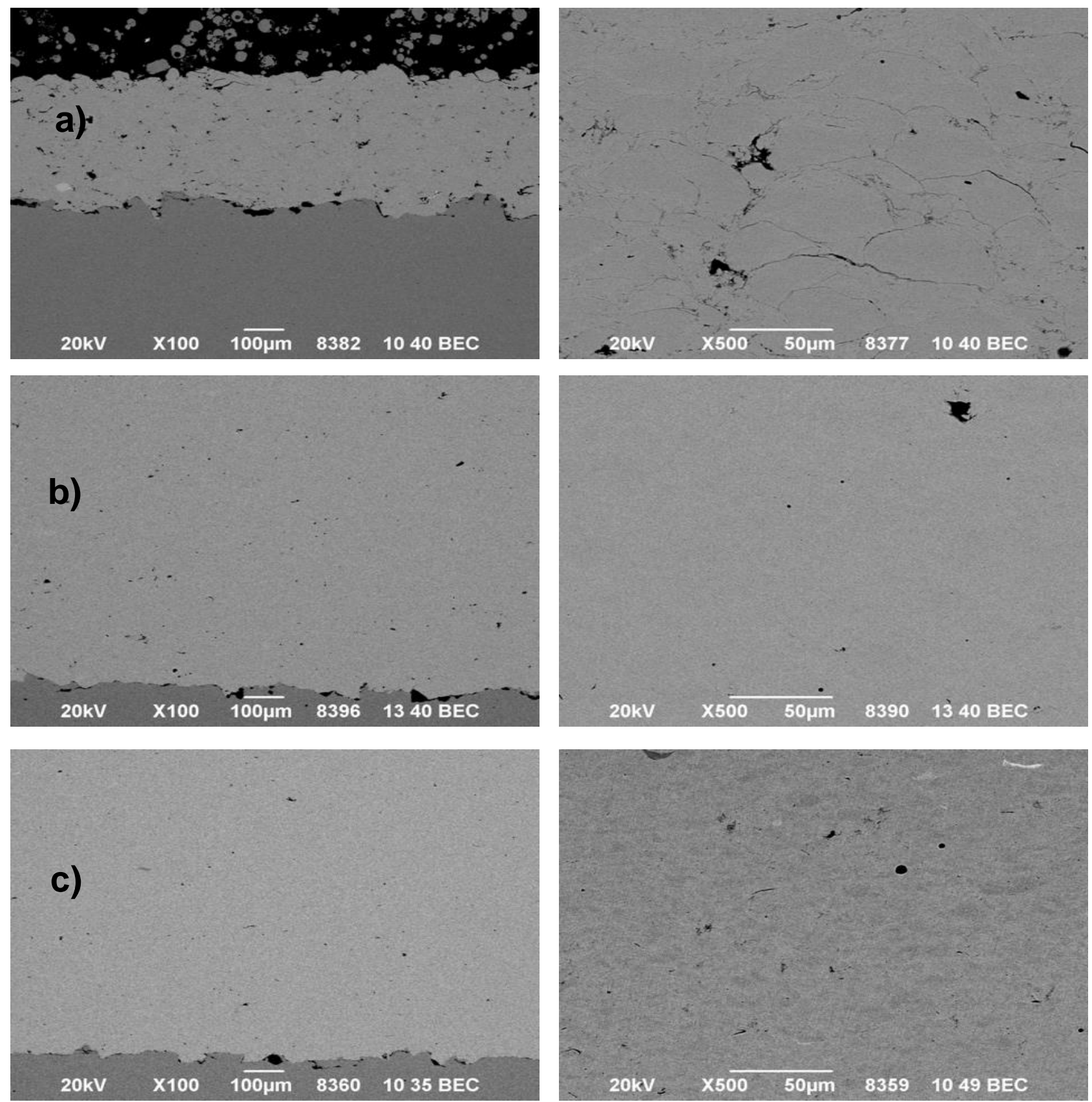

Figure 2 Microstructure of coatings on scanning electron microscope: a) NiCr coating (HVOF sprayed), b) NiCr 10-32 $\mu \mathrm{m}$ (Cold Sprayed), c) NiCr 5-25 um (Cold Sprayed) 


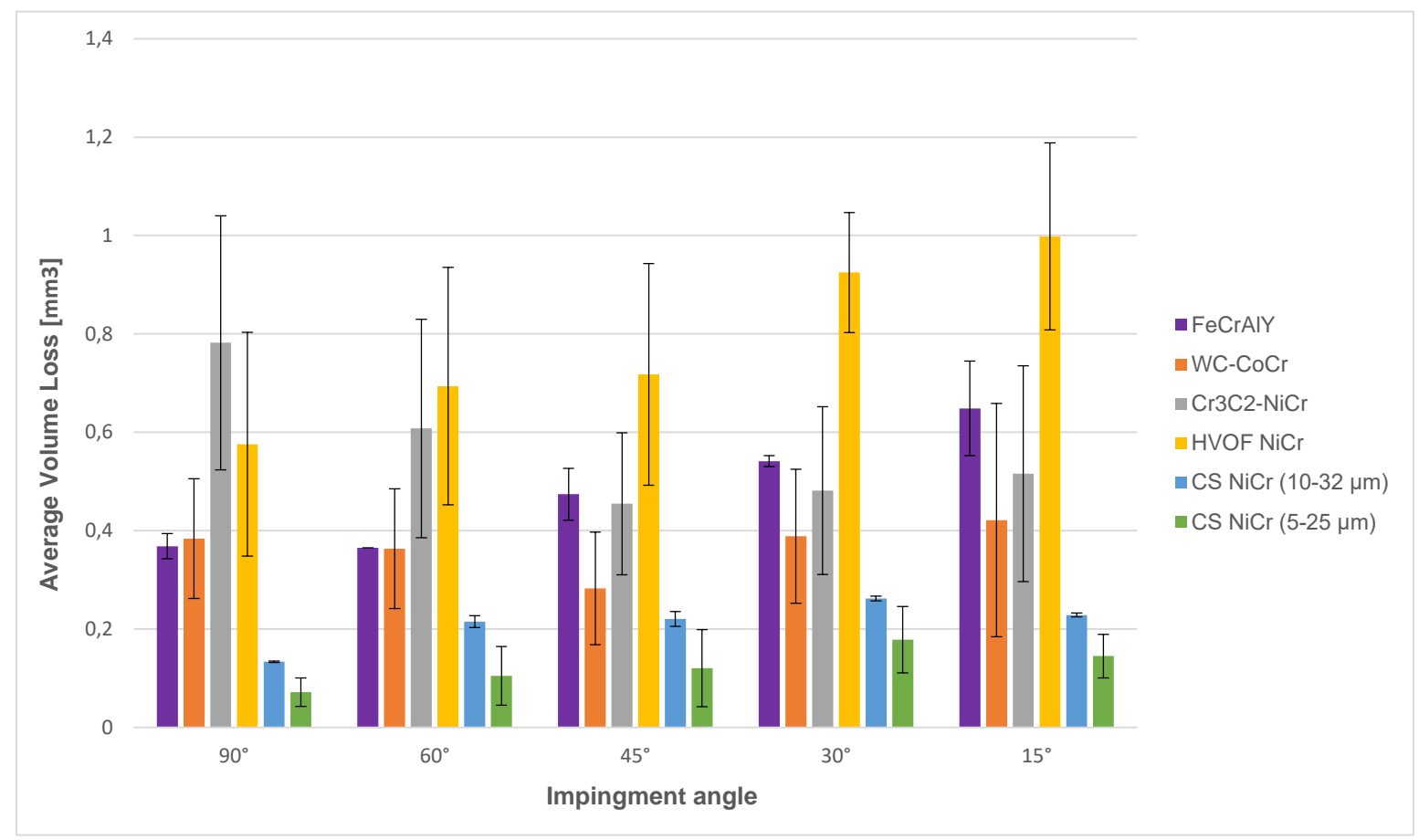

Figure 3 Solid particle erosion wear

\section{CONCLUSION}

The aim of this study was to compare microstructure and solid particle erosion behavior of HVOF and Cold Sprayed coatings with different powder compositions. The microstructure of the individual coatings differed due to the spraying technologies used. The differences between the coatings deposited with HVOF and Cold Spray were significant. In terms of coating homogeneity and porosity, selected coatings can be divided into three groups. FeCrAlY and NiCr (HVOF sprayed) coatings have clearly visible individual boundaries between splat and have lower porosity. For WC-CoCr and $\mathrm{Cr}_{3} \mathrm{C}_{2}-\mathrm{NiCr}$ carbide coatings, the individual phases of the coating are visible as light gray phases with $\mathrm{NiCr}$ or $\mathrm{CoCr}$ matrix and darker phases with $\mathrm{WC}$ or $\mathrm{Cr}_{3} \mathrm{C}_{2}$ carbides. In the case of NiCr coatings deposited with Cold Spray technology, the boundaries of individual splats are not visible, thanks to their completely homogeneous structure and the porosity of the coatings is minimal to zero. Due to the erosive wear by solid particles, the selected coatings behaved as expected due to their structure. The most worn was the HVOF NiCr coating, which had the highest volume losses at all angles except $90^{\circ}$. In terms of the highest volume loss behind it was the $\mathrm{Cr}_{3} \mathrm{C}_{2}-\mathrm{NiCr}$ coating, which had the highest volume loss of all coatings at an angle of $90^{\circ}$. On the contrary, $\mathrm{NiCr}$ Cold Spray coatings showed the lowest volume losses, due to the high erosive wear resistance related to its cohesion between individual splats and high ability to absorb the impact energy. Due to the size and overall fineness of the particles, the $\mathrm{NiCr}$ coating had the lowest volume losses of $5-25 \mu \mathrm{m}$.

\section{ACKNOWLEDGEMENTS}

The paper has originated in the framework of the solution of the National Center for Energy project no. TN01000007.

\section{REFERENCES}

[1] Iron Chromium Aluminum Yttrium (FeCrAIY) Thermal Spray Powder, Material Product Data Sheet [online]. Pfäffikon: Oerlikon Metco, 2017 [cit. 2020-04-06]. Available from: https://www.oerlikon.com/metco/en/productsservices/coating-materials/coating-materials-thermal-spray/mcraly-alloys 
[2] A. WEISENBURGER, A. HEINZEL, G. MÜLLER, H. MUSCHER, A. ROUSANOU, T91 cladding tubes with and without modified FeCrAIY coatings exposed in LBE at different flow, stress and temperature conditions, Journal of Nuclear Materials 376, 2008, 274-281

[3] V. MATIKAINEN, S. RUBIO PEREGRINA, N. OJALA, H. KOIVULUOTO, J. SCHUBERT, Š. HOUDKOVÁ, P. VUORISTO, "Erosion wear performance of WC-10Co4Cr and $\mathrm{Cr}_{3} \mathrm{C}_{2}-25 \mathrm{NiCr}$ coatings sprayed with high-velocity thermal spray processes,"Sufr. Coatings Technol., vol. 370, 2019, pp. 196-212

[4] L. M. BERGER, et al., Thermal Spray: Practical Solutions for Engineering Problems, 1996.

[5] SIDHU, T. S., PRAKASH, S., AGRAWAL R. D. Characterizations and Hot Corrosion Resistence of $\mathrm{Cr}_{3} \mathrm{C}_{2}-\mathrm{NiCr}$ Coating on Ni-base Superalloys in an Aggressive Enviroment, Proceedings of the Journal of Thermal Spray Technology, vol. 15, 2006, s. 811-816.

[6] Š. HOUDKOVÁ, F. ZAHÁLKA, M. KAŠPAROVÁ, L. M. BERGER, Comparative study of thermally sprayed coatings under different types of wear conditions for hard chromium replacement, Tribol. Lett. 43 (2011) 139-154.

[7] N. ABU-WARDA, A. J. J. LÓPEZ, M. D. D. LÓPEZ, and M. V. V UTRILLA, "Ni20Cr coating on T24 steel pipes by HVOF thermal spray for high temperature protection," Surf. Coatings Technol., vol. 381, p. 125133, Jan. 2020, doi: 10.1016/J.Surfcoat.2019.125133.

[8] H.S.SIDHU, B.S.SIDHU, and S.PRAKASH, "Solid particle erosion of HVOF sprayed NiCr and Stellite-6 coatings," Surf. Coatings Technol., vol. 202, no. 2, pp. 232-238, Nov. 2007, doi:10.1016/J.SURFCOAT.2007.05.035.

[9] M. KUMAR et al., "Development of nano-crystalline cold sprayed Ni-20Cr coatings for high temperature oxidation resistance," Surf. Coatings Technol., vol. 266, pp. 122-133, Mar. 2015, doi: 10.1016/J.SURFCOAT.2015.02.032.

[10] M. KAŠPAROVÁ, F. ZAHÁLKA, J. ČUBROVÁ, and Š. HOUDKOVÁ, "Methodology of Evaluation of Erosion Wear Resistance of Materials, Research Report VYZ 1303/10," Pilsen, 2010.

[11] Z. ČESÁNEK and Š. HOUDKOVÁ, "Evaluation of Erosion Wear Resistance of Selected Thermal Sprayed Coatings, Research Report VYZ 1519/2013," Pilsen, 2013.

[12] V. MATIKAINEN, S. RUBIO, N. OJALA, H. KOIVULUOTO, J. SCHUBERT, Š. HOUDKOVÁ, P. VUOROSTO: Cavitation erosion, slurry erosion and solid particle erosion performance of metal matrix composite (MMC) coatings sprayed with modern high velocity thermal spray processes,(2017) Materials Science and Technology Conference and Exhibition 2017, MS and T 2017, 2, pp. 1161-1163.,doi: 10.7449/2017/MST-2017-1161-1163. 